The INL is a

U.S. Department of Energy

National Laboratory

operated by

Battelle Energy Alliance

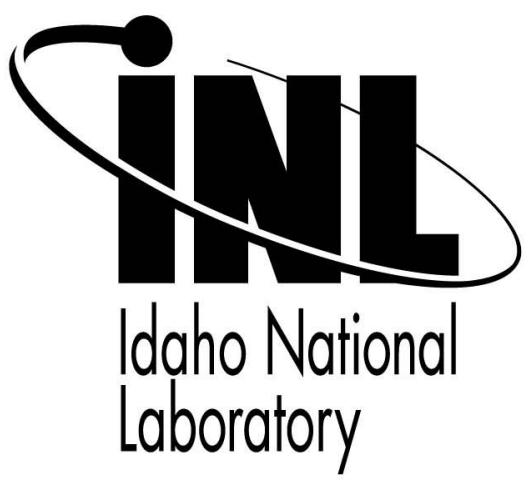

\title{
Development of a New Transportation/Storage Cask System for Use by the DOE Russian Research Reactor Fuel Return Program
}

\section{$15^{\text {th }}$ International Symposium on the Packaging and Transportation of Radioactive Materials (PATRAM 2007)}

Michael Tyacke

Frantisek Svitak

Jiri Rychecky

Miroslav Picek

Alexey Smirnov

Sergey Komarov

Edward Bradley

Alexander Dudchenko

Konstantin Golubkin

\section{October 2007}

This is a preprint of a paper intended for publication in a journal or proceedings. Since changes may be made before publication, this preprint should not be cited or reproduced without permission of the author. This document was prepared as an account of work sponsored by an agency of the United States Government. Neither the United States Government nor any agency thereof, or any of their employees, makes any warranty, expressed or implied, or assumes any legal liability or responsibility for any third party's use, or the results of such use, of any information, apparatus, product or process disclosed in this report, or represents that its use by such third party would not infringe privately owned rights. The views expressed in this paper are not necessarily those of the United States Government or the sponsoring agency. 
Proceedings of the 15th International Symposium on the Packaging and Transportation of Radioactive Materials

PATRAM 2007

October 21-26, 2007, Miami, Florida, USA

\title{
DEVELOPMENT OF A NEW TRANSPORTATION/STORAGE CASK SYSTEM FOR USE BY THE DOE RUSSIAN RESEARCH REACTOR FUEL RETURN PROGRAM
}

\author{
Michael Tyacke \\ Idaho National Laboratory \\ Jiri Rychecky \\ Nuclear Research Institute Řež plc \\ Sergey Komarov \\ R\&D Sosny Company \\ Alexander Dudchenko \\ Federal State Unitary Enterprise (FSUE)
}

\author{
Frantisek Svitak \\ Nuclear Research Institute Řež, plc \\ Miroslav Picek \\ Alexey Smirnov \\ ŠKODA JS a.s. \\ R\&D Sosny Company \\ Edward Bradley \\ International Atomic Energy Agency \\ Konstantin Golubkin \\ FSUE Mayak Production Association
}

\begin{abstract}
The United States, the Russian Federation, and the International Atomic Energy Agency (IAEA) have been working together on a program called the Russian Research Reactor Fuel Return (RRRFR) Program. The purpose of this program is to return Soviet or Russian-supplied high-enriched uranium (HEU) fuel, currently stored at Russian-designed research reactors throughout the world, to Russia. To accommodate transport of the HEU spent nuclear fuel (SNF), a new large-capacity transport/storage cask system was specially designed for handling and operations under the unique conditions at these research reactor facilities. This new cask system is named the ŠKODA VPVR/M cask. The design, licensing, testing, and delivery of this new cask system result from a significant international cooperative effort by several countries and involved numerous private and governmental organizations. This paper contains the following sections: 1) Introduction; 2) VPVR/M Cask Description; 3) Ancillary Equipment, 4) Cask Licensing; 5) Cask Demonstration and Operations; 6) IAEA Procurement, Quality Assurance Inspections, Fabrication, and Delivery; and, 7) Conclusions.
\end{abstract}

\section{INTRODUCTION}

Since December 1999, representatives from the United States, the Russian Federation, and IAEA have been working on a program to return Soviet or Russian-supplied HEU fuel, currently stored at foreign research reactors, to Russia. The primary goal of the RRRFR Program is to advance nuclear nonproliferation objectives by eliminating stockpiles of HEU and encouraging eligible countries to convert their research reactors from HEU to low-enriched uranium (LEU) fuel upon availability, qualification, and licensing of suitable LEU fuel.

Transporting the large quantities of HEU SNF stored at many of the Russian-origin research reactors required that the RRRFR Program identify or develop a new large-capacity cask system. However, not enough existing casks were available to meet the needs of the program; therefore, the decision was made to pursue new cask systems. The IAEA agreed to assist the U.S. Department of Energy (DOE) by sending out a request for proposal and procuring a new cask system. A detailed discussion about IAEA procurement is discussed in the IAEA Procurement, Quality Assurance Inspections, Fabrication, and Delivery section of this paper.

To effectively and efficiently handle this HEU SNF, the IAEA selected a new transport/storage cask system called the VPVR/M cask. This paper provides descriptions of the VPVR/M cask, licensing, demonstration of its use, fabrication, quality inspections and acceptance, and deliverance of 10 of these casks and ancillary equipment.

\section{VPVR/M CASK DESCRIPTION}

The VPVR/M cask is a type $\mathrm{B}(\mathrm{U})$ and $\mathrm{S}$ cask system designed and licensed for transport and storage of SNF from Russian-origin research reactors. The VPVR/M cask has a unique design in that it allows either top or bottom loading/ unloading. The cask consists of a massive, cast steel, cylindrical body. The upper and lower parts of the body are tapered, which was done to minimize the overall cask weight to accommodate the limited overhead crane limits in most research reactor facilities. The cask's internal walls have a hot aluminium spray coating. The SNF basket inside the cask has 36 square ports for holding the assemblies during transport and storage and is 
made out of atabor (boron-treated steel) sheets. A central suspension/hanger rod, running down the middle of the basket, is used to raise or lower the basket out of the cask.

The cask contains a system of two upper and two lower lids, with each lid independently bolted to the cask body. To provide containment during transport and storage, each lid has metallic Helicoflex gaskets. These gaskets are replaced by elastomer o-ring seals when the cask is transported empty. Figure 1 shows a schematic of the cask. Table 1 identifies the cask components and specifications.

The upper and lower primary lids are made of 220-mm (9-in.) thick, stainless steel, cylindrical plates. The upper lid has drying and leak-testing ports that are sealed by shielding plugs when not in use. The upper lid also has a central hole and two side holes used to lower and raise the fuel basket into the storage pools.

The lower primary lid has a specially designed bayonet lock and two threaded pull rods (see Figure 2). The bayonet lock is designed to lock the central suspension/hanger, with two threaded pull rods, to the special lift fixtures for lowering and raising the lid with the basket in the storage pools (see Figure 3). When the central suspension/hanger is not engaged in the bayonet lock, the basket can be lifted out of the cask without the lower lid being attached (see Figure 4).

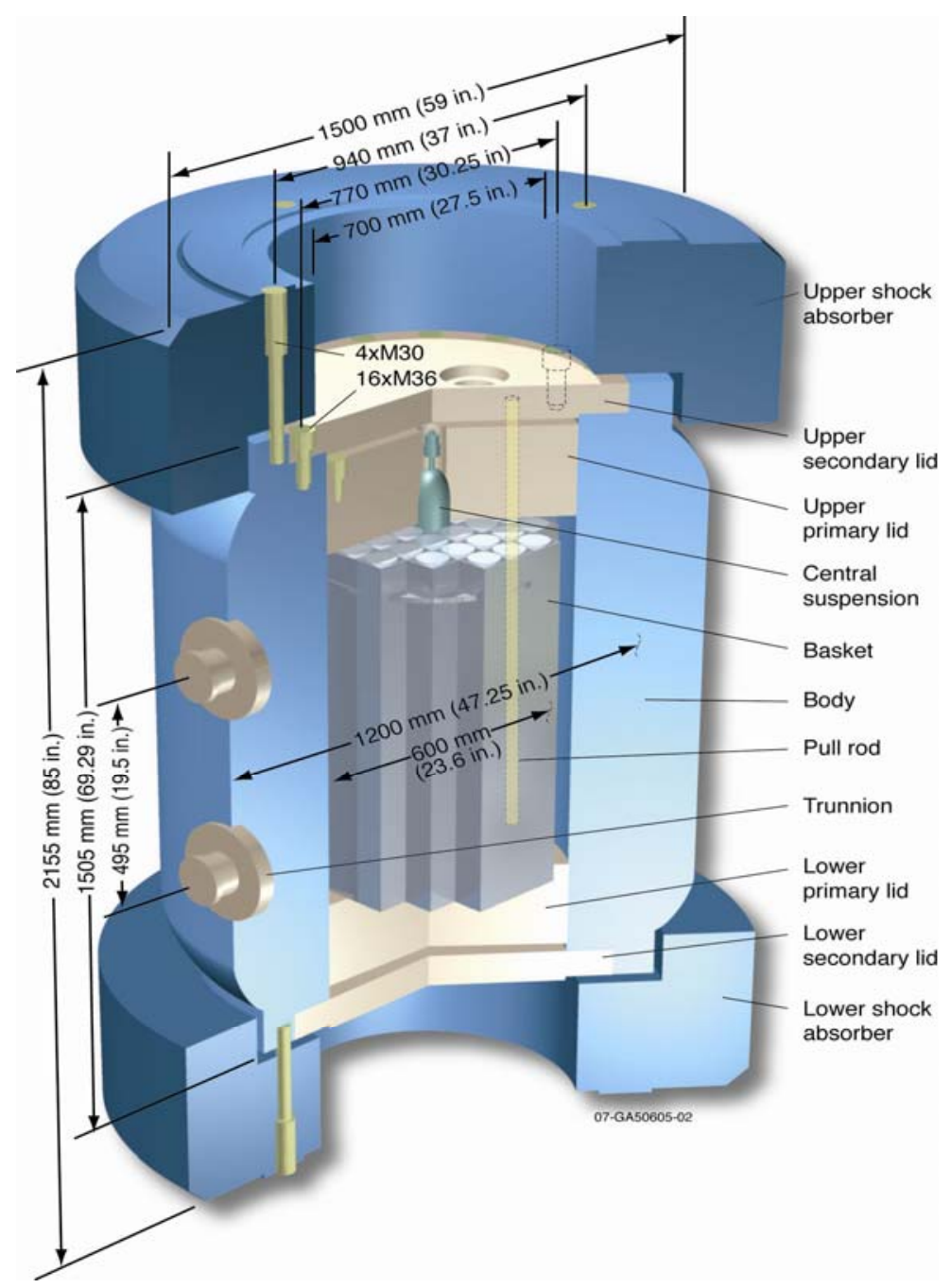

Figure 1. Schematic of the VPVR/M transport and storage cask. Table 1. VPVR/M cask components and specifications.

\begin{tabular}{|c|c|c|c|}
\hline Component & Material & $\begin{array}{l}\text { Dimension } \\
\text { (mm and in.) }\end{array}$ & $\begin{array}{c}\text { Weight } \\
\text { (kg and lb) }\end{array}$ \\
\hline Body & Cast iron & & $10,700 \mathrm{~kg} / 23,589 \mathrm{lb}$ \\
\hline \multicolumn{4}{|l|}{ External } \\
\hline Height (without absorber) & & $1,505 \mathrm{~mm} / 59 \mathrm{in}$. & \\
\hline Diameter & & $1,200 \mathrm{~mm} / 47 \mathrm{in}$. & \\
\hline \multicolumn{4}{|l|}{ Cavity } \\
\hline Height & & $885 \mathrm{~mm} / 35 \mathrm{in}$. & \\
\hline Diameter & & $600 \mathrm{~mm} / 24 \mathrm{in}$. & \\
\hline Wall thickness & & $300 \mathrm{~mm} / 12 \mathrm{in}$. & \\
\hline Basket & $\begin{array}{l}\text { Atabor ( } 1.5 \% \text { boron-treated } \\
\text { steel sheets) }\end{array}$ & $\begin{array}{l}\text { 3.63-mm/0.14-in. thick } \\
833-\mathrm{mm} / 33 \text {-in. high } \\
553-\mathrm{mm} / 22-\text { in. wide }\end{array}$ & $180 \mathrm{~kg} / 397 \mathrm{lb}$ \\
\hline Lids-upper/lower (4) & & & $1,650 \mathrm{~kg} / 3,638 \mathrm{lb}$ \\
\hline Primary_upper/lower & Stainless steel & $\begin{array}{l}\text { 220-mm/9-in. thick } \\
630-\mathrm{mm} / 25 \text {-in. diameter }\end{array}$ & $\begin{array}{l}518 \text { to } 530 \mathrm{~kg} / \\
1,142 \text { to } 1,168 \mathrm{lb}\end{array}$ \\
\hline
\end{tabular}




\begin{tabular}{|r|l|c|c|}
\hline \multicolumn{1}{|c|}{ Component } & \multicolumn{1}{|c|}{ Material } & $\begin{array}{c}\text { Dimension } \\
\text { (mm and in.) }\end{array}$ & $\begin{array}{c}\text { Weight } \\
\text { (kg and lb) }\end{array}$ \\
\hline Secondary-upper/lower & Carbon steel & $\begin{array}{c}80-\mathrm{mm} / 3 \text {-in. thick } \\
840-\mathrm{mm} / 33 \text {-in. diameter }\end{array}$ & $\begin{array}{c}300 \text { to } 316 \mathrm{~kg} / \\
661 \text { to } 697 \mathrm{lb}\end{array}$ \\
\hline Shock absorbers & Carbon steel/wood & $1,500-\mathrm{mm} / 59$-in. diameter & $1,600 \mathrm{~kg} / 3,527 \mathrm{lb}$ \\
\hline Payload (36 assemblies) & & & $450 \mathrm{~kg} / 992 \mathrm{lb}$ \\
\hline Totals & & $\mathbf{2 , 1 5 5} \mathbf{~ m m / 8 5 ~ i n . ~}$ & $\mathbf{1 2 , 3 9 0 ~ k g / 2 7 , 3 1 5 ~ l b ~}$ \\
\hline
\end{tabular}

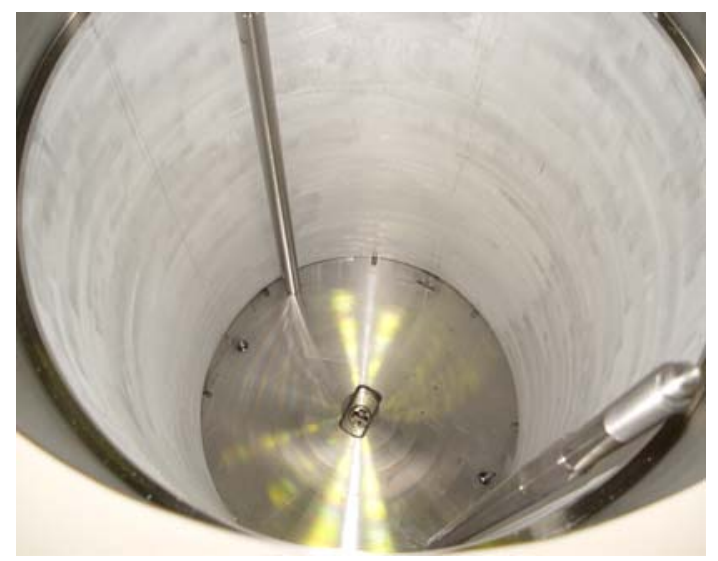

Figure 2. Lower lid central hole with bayonet lock and side pull rods.

The upper and lower secondary lids are carbon steel, $80-\mathrm{mm}$ (3-in.) thick, round plates that fit on a sealing surface inside the cask and are flush to the top and bottom of the cask body outer rim. Both lids have two concentric grooves used to hold the Helicoflex metallic gaskets; these gaskets are needed to seal the cask when it is loaded with SNF. The space between the primary and secondary lids is filled with helium, and a vacuum is pulled between the two seals to check for a leak between the seals. Once the leak test has been successfully performed, the test port is plugged and leak tested. The lower secondary lid does not have vacuum and helium valve ports. Each of the secondary lids is attached to the cask body by $28 \mathrm{M}-36 \times 70$ bolts. Elastomer seals can be used to transport the empty casks.

Each cask has four lifting/handling trunnions, two on each side of the cask. Two shock absorbers are bolted by four M-30 bolts to each end of the cask. The shock absorbers protect the cask and payload in the unlikely event of an accident during transport.

The casks are licensed to be transported by road, railway, river, and sea. The VPVR/M casks are licensed to transport SNF from Russian-origin research reactors. The types of fuels licensed for transport are EK-10, S-36, VVR-M, VVR-M2, VVR-M5, VVR-M7, VVR-(S)M, IRT-2M, IRT-3M, and TVR-S. The types of SNF currently licensed for storage are EK-10, IRT-2M, and IRT-3M (IRT-3M and IRT-2M, with an initial $90 \%$ width enrichment of ${ }^{235} \mathrm{U}$, are not licensed for storage in the VPVR/M casks). Table 2 shows the content allowed in the VPVR/M casks for transport and storage.

\section{ANCILLARY EQUIPMENT}

Ancillary equipment for the VPVR/M cask system includes the basket alignment tool; cask manipulating frame; cask tiedown system; drying/leak-testing equipment; numerous lift fixtures, casks, and fuel-handling tools; and six special-designed and certified International Shipping Organization (ISO) containers. Three cask storage positions exist in the ISO container. The center position is used when one cask is being hauled. The two positions at 
each end of the ISO container are used when two casks are being hauled. The ISO container can only haul up to two casks.

Table 2. Content allowed for transport and storage in a VPVR/M cask.

\begin{tabular}{|l|c|}
\hline \multicolumn{1}{|c|}{ Allowed in VPVR/M Cask } & \multicolumn{1}{c|}{ Maximum Units } \\
\hline Number of assemblies in one cask & 36 \\
\hline Total activity in one cask & $3,93.10^{15} \mathrm{~Bq}$ \\
\hline Residual heat in one assembly & $37,5 \mathrm{~W}$ \\
\hline Total residual heat one cask & $450 \mathrm{~W}$ \\
\hline Allowable ${ }^{235} \mathrm{U}$ in one assembly & $500 \mathrm{~g}$ \\
\hline Minimum cooling times of spent nuclear fuel & Dependent on nuclear fuel burnup \\
\hline Specially designed, stainless steel, hermetic sealed can/sheath & $\begin{array}{l}\text { Damaged fuel assembly, fuel rods, or } \\
\text { parts of fuel rods }\end{array}$ \\
\hline
\end{tabular}

\section{CASK LICENSING}

The VPVR/M cask is licensed for transport in the Czech Republic, Russian Federation, Slovakia, and Ukraine. The Czech Republic licensed the VPVR/M cask for transport and storage under reference number $\mathrm{CZ} / 048 / \mathrm{B}(\mathrm{U}) \mathrm{F}-96$, and its code for international identification is $\mathrm{CZ} / 048 / \mathrm{B}(\mathrm{U}) \mathrm{F}-96$ (Revision 1). This license is valid until July 11, 2011. SKODA JS a.s. submitted the cask licensing application to the Czech State Office of Nuclear Safety (SÚJB) on December 20, 2004. SÚJB evaluated the application against the pertinent requirements in Czech law, Act No. 18/1997 Coll. SKODA provided all material requested from SÚJB and the license was issued March 23, 2005 [1]. The VPVR/M cask meets the requirements of the IAEA recommendations [2] and the international traffic regulations that are referred to by the IAEA [3].

Before the VPVR/M cask, the Russian Federation had never issued a certificate for a packaging design to a cask of foreign design. However, the Russian's have issued licenses for one-time only emergency shipments (e.g., NAC-LWT was licensed to transport HEU SNF by air from Iraq in the 1990s following the first Gulf War). The process for licensing a Type B cask in the Russian Federation is quite complicated. Figure 5 provides a flow chart that shows the licensing process.

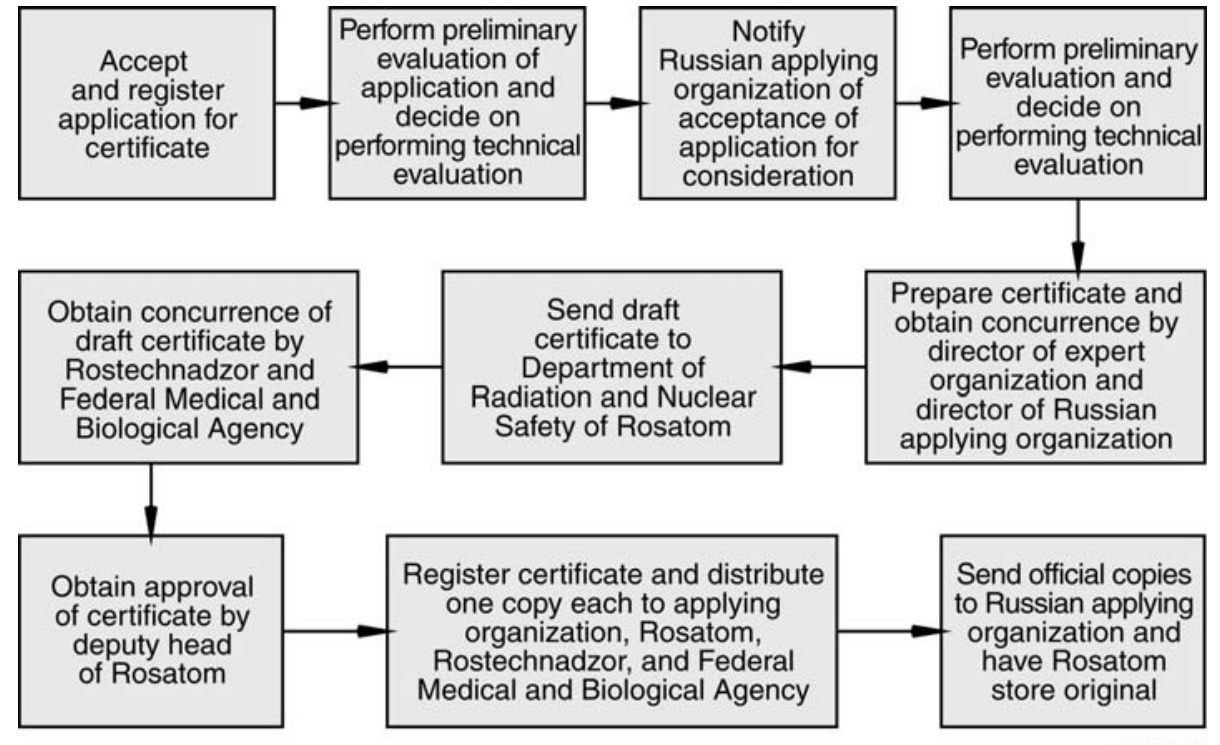

Figure 5. Flowchart showing the process for obtaining a Type B cask certificate in the Russian Federation.

The Sosny R\&D Company, a privately owned Russian company under contract to the Nuclear Research Institute (NRI), managed the technical effort needed for obtaining the Russian certificate. Sosny divided the licensing process into two phases. Phase I verified that the cask design could be licensed in the Russian Federation. Sosny obtained the services of Russian technical experts in licensing of Type B packages in the Russian Federation to review the certification safety documentation provided by SKODA and NRI for licensing of the VPVR/M cask in the Czech Republic. The reviewers evaluated the safety documents to determine if they were sufficient to meet the requirements of the Russian legislation for the safety of radioactive materials transportation. The Russian experts 
identified the following additional safety documentation needed to meet the Russian radiation and nuclear safety regulations: 1) additional structural analysis was needed to show that the package design would not experience brittle fracture under accident conditions at negative environment temperatures (i.e., down to $-40^{\circ} \mathrm{C}$ ); 2) verification of air tightness under emergency conditions after mechanical and thermal total effect; 3) substantiation of vibration resistance during transportation per requirements of the TS-R-1 and NP-053-04 regulations; and 4) verification that a damaged fuel basket and canisters are able to withstand dynamic loads from a container dropped from a height of 9 meters. SKODA provided the analysis and data needed to satisfy these comments.

Phase II involved developing the supporting documents and Russian application [4] for certifying the VPVR/M package design in the Russian Federation. The Russian PVSR-92 regulations [4] required that the shipment consignee in Russia, Federal State Unitary Enterprise (FSUE) PA Mayak, submit the application to Rosatom (the Russian competent authority in the field of atomic energy use).

Two expert organizations under Rosatom, FSUE "VNIIEF" and FSUE "IPPE," performed verification calculations and prepared the documentation needed for demonstrating that the VPVR/M cask design met the International TS-R-1 [3] and Russian NP-053-04 regulations [5]. FSUE "VNIIEF" prepared safety documents that confirmed the structural, thermal, leak tightness, radiation, and nuclear safety of the cask design under normal and hypothetical accident conditions. FSUE "IPPE" provided safety documentation and analysis that demonstrated radiation and nuclear safety for the cask design under normal and hypothetical accident transportation conditions.

Because the VPVR/M cask design had not been subjected to actual testing under hypothetical accident transport conditions (i.e., a drop from 9 meters, puncture test, fire, and submersion underwater), FSUE "VNIIEF" performed a drop analysis from 12 meters to confirm that the cask design had a safety margin. The calculations showed that the cask design has a sufficient safety margin in relation to established dynamic loads. The cask meets Russian Federation requirements from the packaging regulations used to transport fissile materials.

FSUE "VNIIEF" prepared a draft of the Russian certificate. The draft certificate was reviewed and agreed to by NRI Řež, FSUE "PA Mayak," Rosatom Departments, FMBA (i.e., state regulatory body for hygiene and sanitary aspects of radioactive materials safety during transportation), and Rostechnadzor (i.e., state regulatory body for technical aspects of radioactive materials safety during transportation) before being sent to Rosatom for approval. On January 23, 2006, Rosatom approved certificate RUS/3065/B(U)F-96 for the VPVR/M package design. The certificate is valid for 3 years (i.e., until January 23, 2009).

Certifying the cask design for transport through Slovakia and Ukraine was fairly simple because the design is already certified for transport in the Czech Republic and the Russian Federation, and the design meets the IAEA TS-R-1 international transportation requirements. Competent authorities in Slovakia and Ukraine were given copies of the cask design safety documentation and certificates from the Czech Republic and Russian Federation for approval. Both countries approved use of the cask within their territory and did not require a detailed evaluation of the design safety.

\section{CASK DEMONSTRATION AND OPERATIONS}

The VPVR/M cask underwent three demonstrations to verify the design was technically acceptable for handling and loading with fuel at the research reactor facilities, and for receipt and unloading at the Mayak facilities in Russia. The demonstrations were held at the SKODA, NRI, and Mayak facilities. The following subsections provide a summary of those demonstrations.

\section{SKODA Manufacturing Facilities}

The first demonstration was required by the DOE technical team to verify that the VPVR/M cask design was technically acceptable for use by the RRRFR Program. The demonstration was conducted at Plzen, Czech Republic, in a large pit at one end of the SKODA JS a.s. reactor shop manufacturing facility. The demonstration was performed by SKODA technicians in accordance with detailed operating procedure Ae 11 566/Dok, and they used a prototype of the VPVR/M cask. The demonstration included the following: 1) performing a leak test of the top (secondary) lid seals (see Figure 6); 2) removing the top primary lids and the fuel basket (simulating fuel basket unloading at Mayak); 3) lowering the lower primary (inner) lid, with the empty basket attached, from the cask into a pit, and demonstrating the loading of a dummy fuel assembly into the basket (similar to operations to be performed at NRI in $\breve{R}$ ž); and 4) demonstrating the accidental failure of the central suspension/hanger, causing the drop of a full basket.

The tests were all successfully completed. The

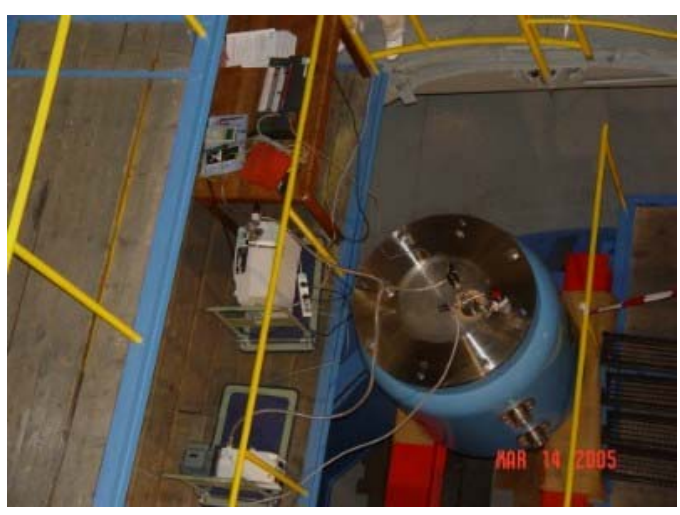

Figure 6. VPVR/M cask leak test demonstration. 
adequacy of the cask design for leak testing, basket top unloading, and bottom loading were confirmed. The drop test showed that the two side-threaded pull rods can withstand a 5-mm drop of a simulated loaded basket if the central suspension/hanger accidentally fails during handling. While the tests were successful, several improvements were identified that could make operations easier and reduce the potential radiation dose to workers.

\section{Nuclear Research Institute Wet Run}

The purpose of the NRI "wet run" was to 1) demonstrate that the newly designed, fabricated, and installed cask and fuel-handling equipment worked properly at the reactor facility and at the high-level waste storage (HLWS) facility; 2) demonstrate that the detailed operating procedures were complete and operational; 3) demonstrate the training of the NRI technicians for handling the ISO container, VPVR/M cask, loading fuel into the basket remotely, and drying and sealing of the cask; and 4) preparing the cask for transport and loading into the ISO container and tying the cask down. A description of the process was provided in the technical resources manual entitled, Demo Test

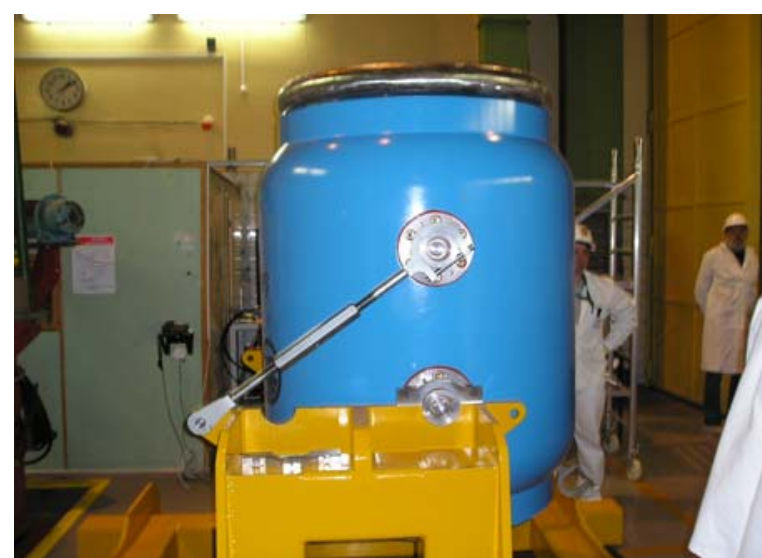

Figure 7. VPVR/M cask secured in vertical position on cask manipulation frame.

Wet Run of the VPVR/M ŚKODA Transport Cask in the Reactor and HLWS Building at the Nuclear Research Institute $\check{R} e \check{z}$ plc. The "wet run" was observed by representatives from the United States, Ukraine, Poland, Russian Federation, Bulgaria, Slovakia, and various organizations from the Czech Republic.

The demonstration started at the reactor facility. The NRI technicians demonstrated removal of the top and bottom lids. Removing the lid from the bottom of the cask requires that it be rotated to the vertical position and secured in place (see Figure 7). The bolts were removed from the lid, and the lid was removed. A sealing surface protector was installed, and a specially designed crush device was installed on the cask bottom outer lid surface and the bottom of the shield plug. The cask was then rotated on the cask manipulation frame so that the top lid could be removed.

A specially designed cask transport carriage was moved by rail from the SNF storage area into the reactor building. The cask was lifted from the cask manipulation fixture and placed onto the transport carriage. The cask was tied down. The loaded transport carriage was moved back into the SNF storage area and secured so that the cask was located directly over a special platform designed to hold the basket during underwater fuel loading into the storage pool (see Figure 8 ). The specially designed basket handling tool was attached to the crane and moved over the cask. The tool center grapple was attached to the basket center rod, then a nut was removed from one of the side rods, and the corresponding rod was installed. The operation was repeated for the second rod. With the basket tool firmly installed, the basket was lowered into the pool and set onto the basket-loading platform. The technicians demonstrated the loading of dummy fuel assemblies into the basket ports that are the hardest to reach from the side of the pool. After fuel loading was demonstrated, the technicians finished filling the basket with dummy fuel assemblies so that the basket and cask would simulate the loaded weight.

The loaded basket was pulled up into the cask. The crane and lift fixtures have been equipped with a digital

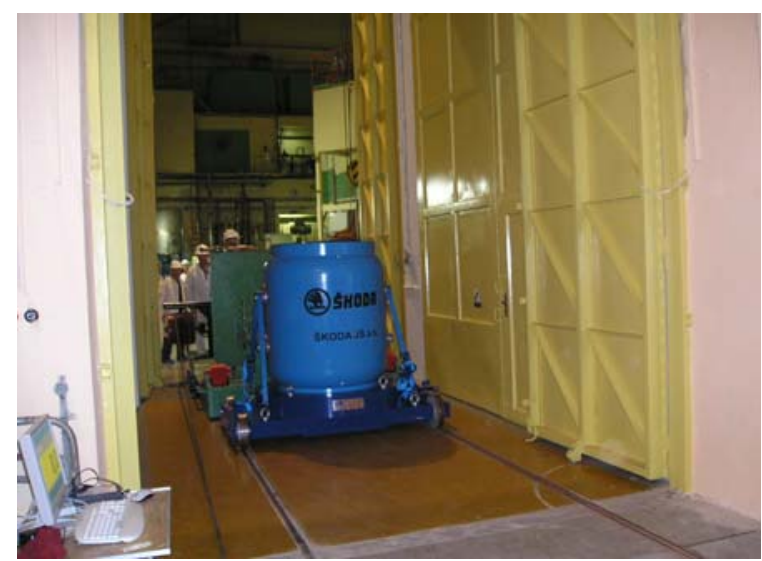

Figure 8. VPVR/M cask being moved into the spent nuclear fuel storage area. dynamometer that is used to monitor the weight of the basket during reinstallation into the cask. Visually, it is not possible to see the basket being lifted into the cask because of shielding that is placed around the cask during that operation. The basket was slowly lifted until it was totally inside the cask body. This was determined by a significant increased weight reading on the dynamometers. The lifting was stopped. The side legs of the lift fixture were disconnected, one leg at a time, from the basket side rods. A nut was used to secure the rod to the cask upper inner lid. This process was repeated for the other side rod. The center basket rod was ungrappled.

The technicians demonstrated installation and removal of the cask shielding. The shielding is needed to protect workers from radiation when the loaded basket is lifted out of the water and before it is totally inside the cask. A nitrogen line was hooked up to the top of the cask, and an off-gas hose was connected between a specially designed port on the shielding around the cask and the facility off-gas system. Heated nitrogen was pumped from the 
top of the cask, through the fuel and basket, and out through the exhaust hose. This is done to remove most of the water before moving the cask back into the reactor area.

The nitrogen hose and exhaust hoses were removed. The cask, loaded with dummy fuel, was transported on the carriage back into the reactor area. The cask was removed from the carriage and placed in the horizontal back onto the cask manipulation frame. Water that was trapped in the basket and crush fixture spilled onto the floor during this operation.

The lids were installed at each end of the cask in reverse of the lid removal operation. A specially designed vacuum-drying system was attached to the port on the bottom lid of the cask. The operators explained how the vacuum-drying system tested and recorded the status of the drying.

The cask was left to dry overnight with the vacuum-drying system operating. The drying was not finished the next morning as hoped because of leakage around the lid seals. The lid had been removed and reinstalled so many times that the seals were not functioning properly. The technicians torqued the lid bolts tighter, and the drying was completed within 2 hours. Helium leak testing equipment was installed, and a lid leak test was demonstrated. Both the inner and outer lid seals were tested.

The lower shock absorber was installed. The transport truck with the specially designed and certified ISO container was backed into the reactor building. The cask was placed into the center cask storage position in the ISO container. The upper shock absorber was installed.

The loaded truck was moved to the HLWS building. The truck had to pass through the village of Řež to get to the facility. A large mobile crane was used to remove the ISO container, with the loaded VPVR/M cask inside, from the truck and place it onto the ground. A transfer carriage, comprised of portable rails with a transfer cart, was set up to receive the cask from the ISO container and move it to the HLWS building loading dock. A transfer carriage was needed because there was not enough room in the loading dock area for the truck to back into and unload the cask from the ISO container.

The cask was transferred by mobile crane from the ISO container to the transfer carriage and tied down. The loaded carriage was moved into the loading dock area (see Figure 9). The upper shock absorber was removed.

The cask was lifted by the facility overhead crane from the cart up to the second level of the storage area and placed on the cask-maneuvering fixture. The bottom shock absorber was removed, and the outer lids were removed as

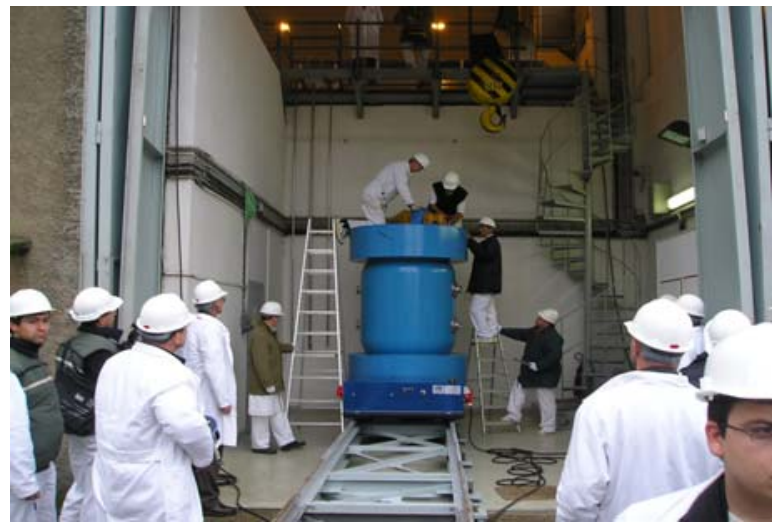

Figure 9. VPVR/M cask being prepared for lifting inside the high-level waste storage building. previously described.

The cask was then transferred from the cask-maneuvering fixture into a specially designed cask loading/unloading bridge that spanned a large empty storage tank. The basket-handling fixture was installed, and the loaded basket was lowered to the bottom of the tank. The technicians demonstrated removal of several dummy fuel assemblies. The demonstration was stopped at this point. All follow-on activities had already been demonstrated.

The "wet run" was very successful; however, the following improvements were identified: 1) a catch pan for water from the crush pad and holes may need to be made in the tubing so that water can drain out; and 2) the metallic Helicoflex seals need to be changed out for elastomer seals to transport the empty cask. The Helicoflex seals are very expensive and hard to reuse.

\section{Mayak Dry Run}

The third demonstration was performed at the FSUE Mayak Production Association facilities in Ozyorsk, Russia. The purpose for the dry run was to 1) demonstrate the setup of cask-handling and auxiliary equipment in the Mayak facilities; 2) demonstrate that detailed operating procedures were complete and operational; 3) demonstrate training of the Mayak technicians for handling the ISO container and VPVR/M cask and unloading the basket remotely; and 4) perform cask maintenance in preparation for loading the empty cask for transport and loading it into the ISO container, tying it down, and returning it to the originating facility. The dry run was attended by representatives from the Czech Republic (e.g., NRI and SKODA), DOE, FSUE Mayak, Sosny R\&D Company, and Rostechnadzor.

Sosny prepared a special report [6]; this report identified the unit under test, test objectives, general information, safety measures, test preparations, scope of work and conditions of test performance, and conclusions and recommendations. Equipment developed and fabricated to handle the VPVR/M cask at FSUE Mayak included 1) equipment for acceptance and unloading of ISO containers; 2) specially designed and fabricated fixture for holding VPVR/M casks inside the special railcar wagon container for transporting the VPVR/M cask within the 
plant; 3) a remote-control device to operate overhead crane and a frequency converter to control the crane velocity during cask and basket-handling operations; and 4) miscellaneous vertical spacers, adapters, captures, and rods.

Before beginning the dry run, the FSUE Mayak representative discussed the problems they had encountered during receipt of the equipment. The most significant problems include the following: 1) lack of preparation time because the equipment took longer than planned to travel from Řež, Czech Republic, to FSUE Mayak in Ozyorsk, Russia; 2) some of the equipment did not work because it needed different bolts; 3) there were problems getting through customs because some of the numbers did not match the manifest numbers; and 4) the cask tiedowns were loose upon arrival and bolts from the bottom shock absorber had fallen out.

The dry run began in the building for vehicle preparations where the railcar, ISO container, and VPVR/M cask were staged. The fixture for the ISO container did not fit; therefore, it had to be modified before the ISO container was lifted off the railcar. The dry run began with removal of the ISO container lid. Then the bolts attaching the upper shock absorber to the cask were removed, and the upper shock absorber was removed and placed in storage. The tiedowns were removed after operational personnel explained how the tiedowns were loose upon arrival at Mayak from Řež. The cask, with lower shock absorber attached, was removed from the ISO container and placed onto the cask manipulation frame and rotated to the horizontal position. The lower impact was removed and placed in storage. At this point, Mayak personnel showed how the bolts falling out of the lower shock absorber during transport from Řež to Mayak caused the rubbing/gouging marks on the inside of the shock absorber. They also showed that the upper cask trunnions were gouged as a result of tiedowns loosening during transport.

The cask was lifted from the cask manipulation frame to the vertical position and moved to a specially designed hopper with a lid-type railcar used for Mayak onsite fuel movement operations. The cask was lifted up over the side of the railcar and placed in a specially designed and fabricated fixture for the VPVR/M casks. The cask was not tied down inside the railcar during onsite transport because the train is limited to $5 \mathrm{k} / \mathrm{hr}$ during transport. The loaded railcar was moved into the hot shop/pool area in the building for unloading. The hot shop is a large narrow high bay with rail access, two specially designed overhead cranes with cages, and different grapples for different operations. There is a wall between the high-bay, cask-handling room and the large SNF storage pools. There are specially designed shoots, with carts, to transfer the loaded SNF basket from the cask into the storage pool. The cask was depressurized and a gas sample was taken before removing the outer (secondary) lid from the cask (see Figure 10). The outer lid was removed, stored, and a seal-protection cover was installed in the cask. The inner (primary) lid was removed and stored. The Mayak representative explained that under normal circumstances, all operations from this point forward would be done remotely and all personnel would be required to leave the high-bay area. The representative explained that the remote operations are performed, using special lighting and cameras, in a special control room that is shielded from the high bay.

The basket loaded with dummy fuel assemblies was lifted out of the cask, over a wall, and placed inside the specially modified fuel-handling cart for holding the VPVR/M fuel basket (see Figure 11). The cart was lowered into the SNF pool. The Mayak operators then demonstrated removal of the dummy SNF assemblies from the cask basket and placement of them into the Mayak storage basket. The pool is set up with three emptied

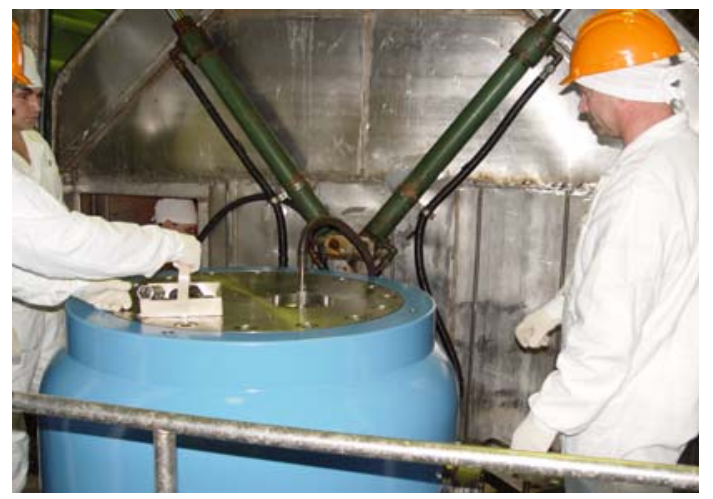

Figure 10. Mayak technicians depressurizing before opening the VPVR/M cask lid.

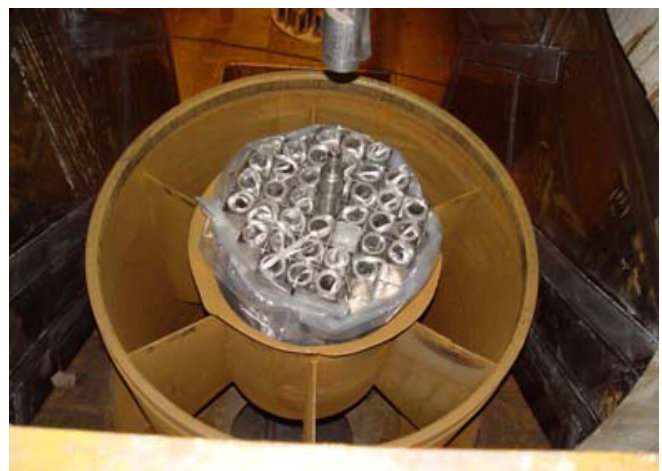

Figure 11. VPVR/M cask basket inside the specially modified Mayak storage pool fuel-handling cart. baskets so that the emptied basket can be moved to a special decontamination facility for cleaning before reloading into the cask. This operation was not demonstrated.

After demonstrating the unloading of fuel from the basket, the cask was reassembled and returned to the building for vehicle preparations. The cask was disassembled in order to demonstrate assembly of the cask after decontamination. The operations were as follows: first, the outer lid was turned over and the metallic seals were replaced with elastomer seals. The lid was then lifted and turned over for placement onto the cask. The outer elastomer seal fell out of the lid seal groove, preventing the operation from being completed. The plastic seal holder used for the metallic seals was not designed to hold both the inner and outer seals in place. As a temporary solution to the problem, the Mayak operations personnel used grease to hold the seal in place while the lid was installed on 
the cask. Second, the lower primary lid with the basket was installed, followed by installation of the bottom secondary lid. Third, the central suspension/hanger was installed in the bottom primary lid. Fourth, the basket was placed in the cask and the upper primary lid was installed. Fifth, the outer secondary lid was installed. Sixth, the cask was rotated to the horizontal position and a pressure test of the cask assembly was successfully performed. Seventh, the lower shock absorber was installed and the assembled cask was placed into the ISO container and tied down. Finally, the upper shock absorber was installed, which concluded the dry run.

The dry run was a success, and the Mayak operations personnel, procedures, and the VPVR/M cask system were adequately demonstrated. Areas of improvement identified include the following: 1) information provided to Russian customs needs to be accurate; 2) all bolts need to be lubricated and inspected before each use; 3) a quality assurance inspector, or equivalent, needs to independently verify critical operations; 4) a load cell should be used for most lifts to ensure that cask components and fixtures are not overstressed; 5) the lid seal holder needs to be redesigned; 6) the tiedown and bottom shock absorber bolt problem needs to be formally documented, evaluated, and a disposition identified and approved; 7) a special tool needs to be designed for removing the seals; and 8) care needs to be taken to ensure that the stainless-steel components of the cask are not exposed to carbon steel contamination.

\section{IAEA PROCUREMENT, QUALITY ASSURANCE INSPECTIONS, FABRICATION, AND DELIVERY}

The DOE RRRFR Program did not have a high-capacity cask and enough total casks to haul all of the HEU SNF from NRI to Mayak in one shipment. To assist in resolving this problem, the IAEA agreed to use their procurement system to send out a request for proposal and procure enough casks to meet the NRI shipment needs.

On July 25, 2005, the IAEA issued the request for proposal [7]. October 24 through 28, 2005, an evaluation group, consisting of five international expert consultants, was convened at the IAEA headquarters in Vienna to perform a technical review and evaluation of the bids submitted in response to IAEA's procurement request. The financial evaluation of the proposals was completed by a different, independent group. Technical experts evaluated cask systems' proposals from six international cask vendors.

All of the vendors provided proposals that met at least parts of the scope of the request for proposal. However; only one of the suppliers, SKODA JS a.s., offering the VPVR/M cask system, met all of the scope requirements. The SKODA proposal not only met all of the scope requirements, but also provided additional benefits to the program. The SKODA proposal 1) committed to deliver 10 units within 10 months of the contract awarding; 2) had already licensed the cask for transport and storage in the Czech Republic and were in the process of licensing it in the Russian Federation, Ukraine, and Slovakia; 3) had NRI offering to provide, to the RRRFR Program, their six VPVR/M casks (adding the ability to haul an additional 216 spent fuel assemblies) after completing the transfer of their LEU fuel to Russia; 4) had much of the preparations for handling the cask system already in place at NRI Řež; and 5) the cask system was confirmed to be acceptable for use at Mayak.

A tripartite contract, finalized in December 2005, between IAEA, ŠKODA JS a.s, and Ústav jaderného výzkumu Řež a.s. (NRI Řež, plc) formalized an initial order for eight VPVR/M casks, and shipping containers, tooling, and other ancillary equipment as shown in Figure 12. The contract included extensive fabrication, inspection, and testing provisions; licensing and quality requirements; and an option for the purchase of two additional casks, which was later exercised by IAEA. An inspection plan was developed to manage contract implementation. This plan was implemented through a series of factory inspections at the ŠKODA JS a.s. manufacturing facilities.

In addition to provision of the casks and related ancillary equipment, the contract scope included certain licensing and demonstration requirements. To fulfill the contract,

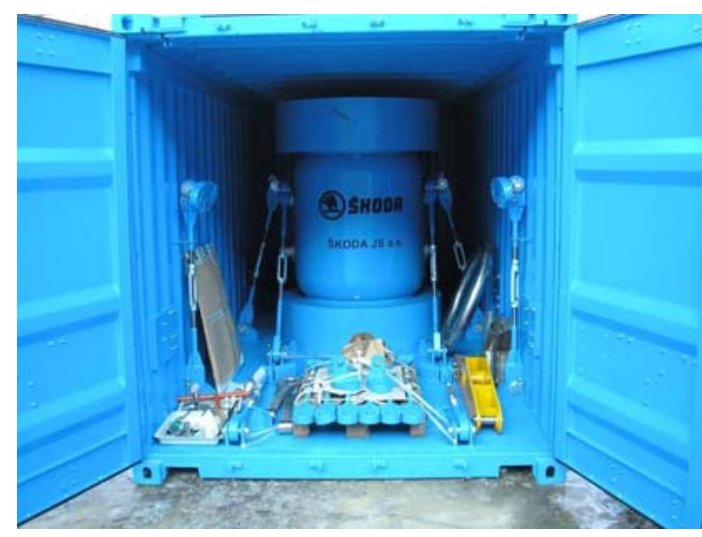

Figure 12. SKODA VPVR/M cask and ancillary equipment.

the supplier was required to either obtain a license for the cask or satisfy all necessary requirements to obtain an eventual license in the Czech Republic, Russian Federation, Ukraine, and Slovakia. In March 2005, before signing the contract, the cask license had been obtained within the Czech Republic. Following a rigorous, independent technical review, the cask system was subsequently licensed within the Russian Federation. The Ukraine license followed a few months later. Discussions between NRI Řež and Slovakian officials provided adequate assurance that the cask system met the licensing requirements within Slovakia.

The contract split the manufacturing inspections into an initial quality audit and five factory acceptance inspections. A contract review meeting held in January 2006 developed the initial schedule. The audit and 
inspections were then completed as indicated in the timeline shown in Figure 13. During the quality audit, IAEA reviewed the supplier's quality system, including the Fabrication, Test, and Inspection Plan and relevant hold/witness points. During subsequent factory acceptance inspections, several tests were witnessed (e.g., leak tests, load tests, and die penetrant tests) and the Fabrication Data Packages (one for each cask) were reviewed and accepted by IAEA and observed by DOE. Final acceptance was completed by IAEA and NRI Rež.

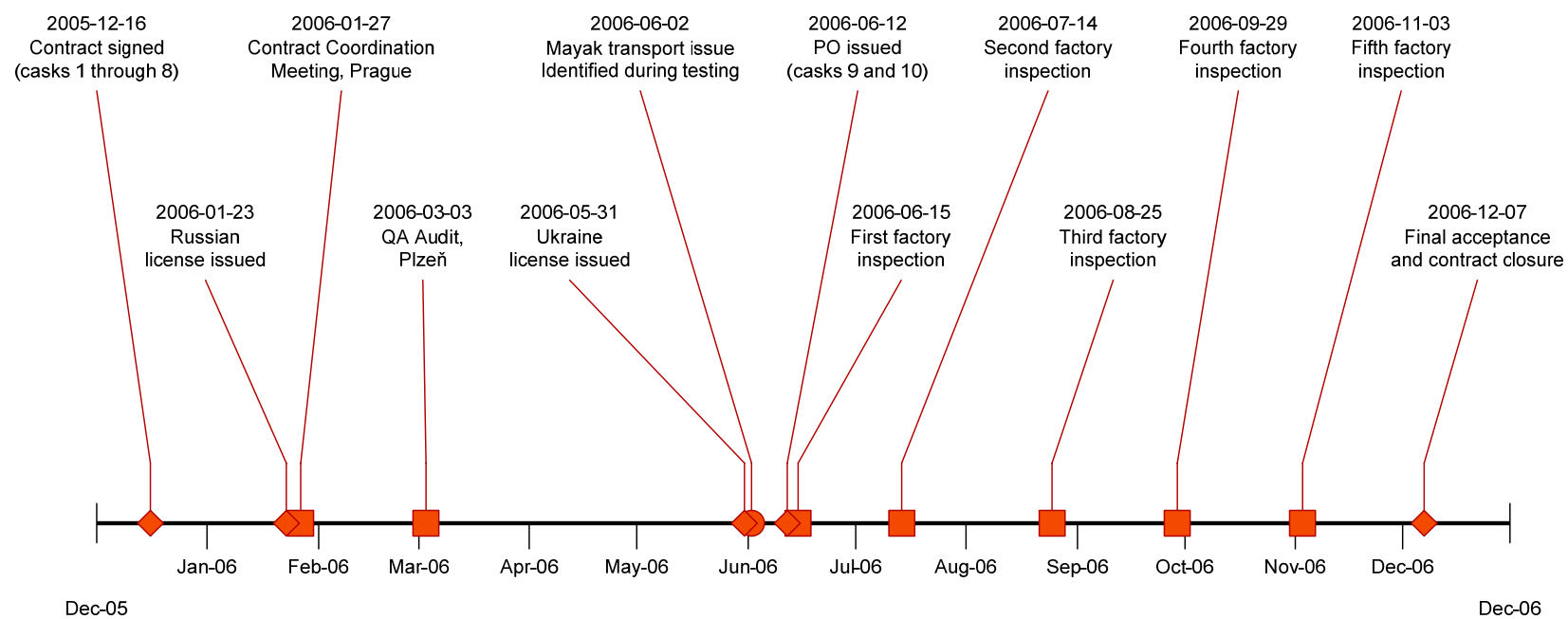

Figure 13. International Atomic Energy Agency contract for the VPVR/M cask procurement timeline.

In parallel with manufacturing, a dry run test, previously discussed, was performed in the fuel processing facility at Mayak. This evolution helped identify needed improvements in the cask-handling and tiedown systems. The fairly harsh conditions involved in rail transport from the Czech Republic to the Mayak facility managed to loosen turnbuckles, which then allowed the casks to undergo fairly rapid, vibration-induced wear as shown in Figure 14. While the cask satisfied all requirements with regard to its interface with the Mayak facility, the transport issue resulted in a significant review and overhaul of the tiedown system. The review considered the tiedown system condition before shipment, the as-found condition at Mayak, and the principal and contributing causes. Following a thorough review by all relevant stakeholders, including the regulator, a corrective action report was released that detailed the above information and recommended design modifications and follow-up testing. Tests included further rail transport under both normal and artificially harsh conditions. All recommendations of the report were subsequently implemented, and all testing was

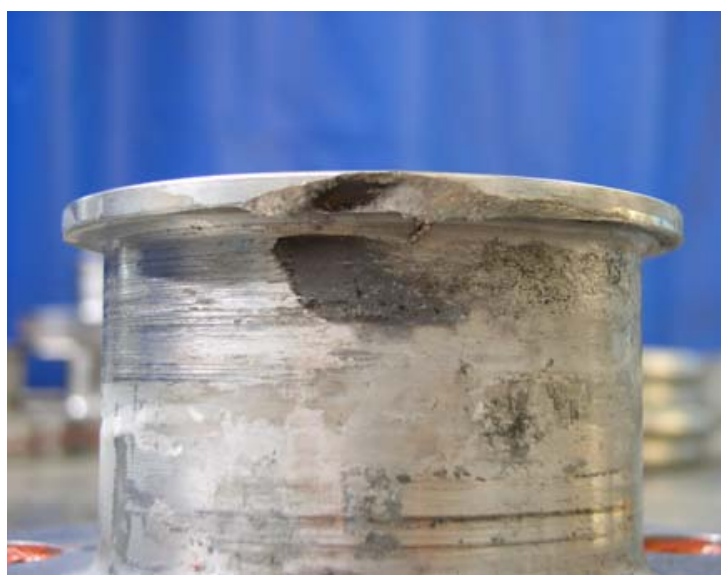

Figure 14. Cask trunnion wear resulting from loosening of the tiedown system during transport of the VPVR/M cask between NRI in Rez and Mayak in the Russian Federation. concluded in time to supply the $10 \mathrm{VPVR} / \mathrm{M}$ casks without adversely affecting the quality, cost, or schedule.

\section{CONCLUSIONS}

The VPVR/M cask is an excellent cask system for use by the RRRFR Program to transport HEU SNF from the various Russian-origin research reactors throughout the world to Mayak in the Russian Federation. The cask is licensed in four countries: Czech Republic, Russian Federation, Slovakia, and Ukraine. The VPVR/M cask is the first foreign cask to be licensed for multiple uses in the Russian Federation. It is licensed to be transported by road, railway, river, and sea. The cask is also licensed to transport 10 fuel types and to store three fuel types from Russian-origin research reactors.

The VPVR/M cask was specially designed for handling in Russian-origin research reactor facilities. It is a high-capacity cask. Each cask has a 36-assembly capacity. There are 16 casks total (10 casks procured by IAEA for DOE and 6 casks procured by NRI), with a total capability for transporting 576 assemblies. 
The VPVR/M cask has unique features for accommodating the special needs of the Russian-origin research reactor facilities. The top and bottom loading and unloading feature makes the cask especially convenient and efficient for use in the limited areas and overhead crane capacities at most of these reactor facilities.

The cask system, with all features, has been thoroughly demonstrated at the SKODA JS a.s. manufacturing facilities in Plzen, Czech Republic; NRI facilities at Řež; and Mayak facilities in Ozyorsk, Russia. Improvements, deficiencies, and lessons learned from those demonstrations have been incorporated and corrected to improve the operability of the cask system.

The first RRRFR Program shipment to use these casks will be the LEU and HEU SNF from NRI at Řež in the Czech Republic. All 16 casks will be used for that shipment. The shipment is scheduled to be made the last quarter of 2007. Following completion of the NRI shipment, the casks are scheduled for use in other countries (e.g., Bulgaria, Hungary, and Poland).

Also, an effort is underway to evaluate licensing of a modified VPVR/M cask design as a Type $\mathrm{C}$ air transport cask. If successful, the casks may be used to transport SNF from countries with difficult transport requirements, such as Libya and Vietnam.

The successful implementation of the IAEA tripartite contract for supply of the $10 \mathrm{VPVR} / \mathrm{M}$ casks reflects the significant and cooperative effort of numerous individuals within several organizations. The audit and inspection plans developed early in the process were fully executed while the team worked to address the issues identified during the Mayak demonstration. It is worthy to highlight that this challenge was overcome and the entire scope was fulfilled without impacting the quality, schedule, or budget, and in a manner that precluded any additional inspections.

\section{REFERENCES}

[1] Czech Law, Act No. 18/1997 Coll., on Peaceful Utilization of Nuclear Energy and Ionizing Radiation (the Atomic Act) and on Amendments and Additions to Related Acts and, Czech Regulatory Body (SÚJB SONS State Office for Nuclear Safety) Decree

Decree of the SÚJB No. 317/2002 Coll., on Type Approval of Packaging Assemblies for Transport, Storage and Disposal of Nuclear Materials and Radioactive Substances, on Type Approval of Ionizing Radiation Sources and on Transport of Nuclear Materials and Specified Radioactive Substances ("on Type Approval and Transport"), Annexes. (Repeals Decrees Nos. 142/1997 Coll. and 143/1997 Coll.)

Decree of the SÚJB No. 307/2002 Coll., on Radiation Protection, Annexes 1-13 (Preliminary version) Decree of the SÚJB No. 214/1997 Coll., on Quality Assurance in Activities Related to the Utilization of Nuclear Energy and in Radiation Activities, and Laying Down Criteria for the Assignment and Categorization of Classified Equipment into Safety Classes.

[2] IAEA, 2004, "Edition of the IAEA Safety Standard, Rules for Safe Transport of Radioactive Materials, Issue 2003, Requirements," Ref. No. TS-R-1, Vienna.

[3] IAEA Regulations - Safety Standards Series

IAEA Regulations for the Safe Transport of Radioactive Material 1996 Edition (As Amended 2003) Safety Requirements, IAEA Safety Standards Series No. TS-R-1 (ST-1, Revised)

Advisory Material for the IAEA Regulations for the Safe Transport of Radioactive Material, IAEA Safety Standards Series No. TS-G-1.1 (ST-2), 2002

Planning and Preparing for Emergency Response to Transport Accidents Involving Radioactive Material, IAEA Safety Standards Series No. TS-G-1.2 (ST-3), 2002

IAEA International Basic Safety Standards for Protection against Ionizing Radiation and for the Safety of Radiation Sources, Safety Series No. 115, IAEA, Vienna, 1996.

[4] PVSR-92, 1992, "Temporary regulation on issuing certificates for radioactive materials of special type, package design and shipment of the packages with radioactive materials."

[5] Rostechnadzor, 2005, "Safety rules at radioactive material shipment," NP-053-04.

[6] Sosny, "Analysis of the Proper Use Test Results of SKODA VPVR/M Cask and Support Equipment," No. 0-109-07.

[7] IAEA, 2005, "Request for Proposal RER 4028-004-003A-Supply of a Research Reactor Spent Fuel Transport and Storage Cask System to be used for the Repatriation of Research Reactor Spent Nuclear Fuel to the Russian Federation." 